Portland State University

PDXScholar

6-16-2021

\title{
High-Stakes Education: Dual Language Immersion in Portland, Oregon
}

Andrew MacLean

Portland State University

Follow this and additional works at: https://pdxscholar.library.pdx.edu/honorstheses

Part of the Bilingual, Multilingual, and Multicultural Education Commons Let us know how access to this document benefits you.

\section{Recommended Citation}

MacLean, Andrew, "High-Stakes Education: Dual Language Immersion in Portland, Oregon" (2021).

University Honors Theses. Paper 1093.

https://doi.org/10.15760/honors.1120

This Thesis is brought to you for free and open access. It has been accepted for inclusion in University Honors Theses by an authorized administrator of PDXScholar. Please contact us if we can make this document more accessible: pdxscholar@pdx.edu. 
High-Stakes Education: Dual Language Immersion in Portland, Oregon

by

Andrew MacLean

An undergraduate honors thesis submitted in partial fulfillment of the requirements for the degree of

Bachelor of Arts

In

University Honors

And

Applied Linguistics

Thesis Adviser

Dr. Kimberley Brown

Portland State University 


\section{High-Stakes Education: Dual Language Immersion in Portland, Oregon}

In the United States there is an increasing amount of programs that are teaching languages: foreign language programs in high schools and colleges, English as a Second Language programs, English for Academic Purposes, and immersion grade school experiences set up to help heritage learners and foreign language learners alike. Second Language Acquisition (SLA) researchers in North America at large have spent much time considering how to improve the quality of SLA pedagogy, because learning an additional language carries potent potential benefit for individuals and society as a whole. For those that Applied Linguists and educators call English Language Learners (ELLs), learning an additional language (Lx) (in this context, English) is actually vital for their ability to not only assimilate into society, but to also have access to economic opportunity and security. ELLs in the United States traditionally have faced what education researchers have called an "Achievement Gap" (Collier and Thomas 2004, Reardon and Galindo 2009, Valentino and Reardon 2015), whereby they (the ELLs) have been provided with limited English instruction, while often falling behind their native-English-speaking peers in core academic content. Improving the system through which all American students matriculate whether they are ELLs or native speakers of English, is a matter of fair, equitable treatment and social justice. Looking past the ELL demographic which includes (but is not limited only to) people from the Americas, Europe, Asia, Pacific Islands and Africa, there are also societal and personal needs for 
multilingualism in the US- whether English is L1 or Lx. From the perspective of the nation at large, multilinguals are in high demand and short supply at both the local and national levels (Sutcher et al., 2019, p. 6): The government needs multilingual public servants that can work in health, diplomacy, national defense, social services, education, and beyond. On the personal level, people benefit cognitively, socially, and economically from multilingualism. Research has shown that maintaining a language additional to the first language can delay or reduce the impact of age-related mental decline, while also increasing academic performance earlier in life (Bialystok 2007, Esposito and Baker-Ward 2013 ). Socially, multilingual peoples are more likely to be empathetic towards out-groups and have more friends (Collier and Thomas 2004, p. 11). Economically, businesses, institutions and governments across all sectors are increasingly valuing multilingualism in the workplace, making any multilingual applicants more competitive than monolingual peers (Gandára and Acevedo 2016). The benefit of SLA for all is well established, and a number of US federal and local policies over the past sixty years have provided funding and implementation support for public ELL and Foreign Language Learner (FLL) programs. This research will serve to show how one specific bilingual education program in Portland, Oregon, provides high-impact services for ELLs and FLLs, meets state and federal requirements, and is sustainable for the future.

\section{Language Planning and Second Language Acquisition}


The first phase of this research aims to present a framework for identifying elements of second language acquisition (SLA) inside and outside the classroom. The reason for providing fundamental concepts from SLA in this project is to add credibility to the claim in this paper that DLI programs are effective for both ELLs and FLLs and deserve additional support at the highest level. Throughout this presentation connections will be drawn between the following concepts and the combination of policies and outside research data utilized. The main unifying framework comes from James W Tollefson, a distinguished researcher of language policy and planning at the University of Washington. Tollefson has said this about the US' attitude regarding multilingualism compared to other countries: "Outside the United States.. Multilingualism is often the rule rather than the exception, and the acquisition or learning of second or foreign languages is often planned rather than accidental" (Tollefson, 1981, p. 337). With this statement Tollefson is contrasting the planned multilingualism common in other nations' education systems to the less cohesive approach in the United States. In this journal article written by Tollefson from 1981, called The Role of Language Planning in Second Language Acquisition as it appears in the journal Language Learning: A Journal of Research in Language Studies, Tollefson creates a framework for understanding language policy and implementation in terms of SLA. This framework has informed the research on language policy in this evaluative paper. Tollefson's framework of language acquisition is an extension of Merrill Swain's model of second language acquisition, which includes the four following variables impacting eventual 
attainment of an additional language (Lx): Input, Learner, Learning, and Learned variables. Tollefson describes these variables in Tollefson 1981:

Input variables affecting SLA are divided into natural interaction, involving native speakers, and instructional interaction, involving teacher-student and student-student interaction... Learner variables include attitude and motivation, ego permeability and other personality factors such as sensitivity to criticism and tolerance of ambiguity... Learning variables include unconscious acquisition processes and conscious learning strategies (Krashen 1976, 1978). Learned variables include the grammatical and pragmatic structural systems which learners must acquire.

In addition to these four variables, Tollefson introduces a hierarchy of planning variables that affect SLA from an organizational perspective. Figure 1 (Tollefson 1981) contains a flowchart of the following variables: Language Situation Variables, Macro-Policy Goals, Macro-Implementation Decisions, Micro-Policy Goals and Micro-Implementation Decisions, which then lead to Swain's four original SLA variables. 
Figure 1, Tollefson 1981

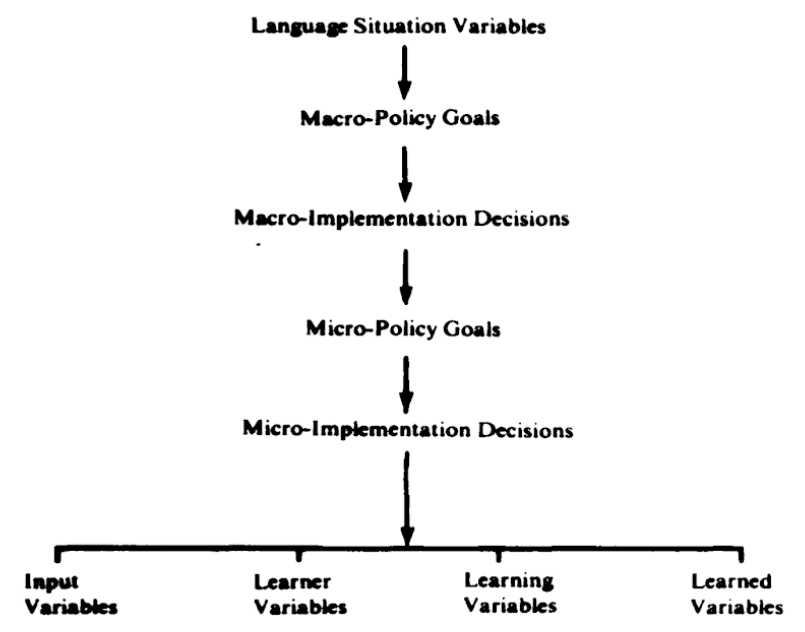

Language Situation Variables are a set of factors that are summarized as follows in Tollefson 1981: "Who speaks what language varieties to whom for what purposes".

There are additional variables embedded in each element of the preceding statement. Who involves variables of age, socioeconomic status, ethnic and regional groups. Speaks varies in terms of proficiency level. What language varieties means the variation of social and regional dialects, registers, and autonomous languages. To whom is again about age, socioeconomic status, ethnic and regional groups, etc.. For what purposes for example are business and trade, religion, education, and government activity. Tollefson lists three ways in which the Language Situation can factor into SLA: Language contact, the role of language in sociopolitical structure, and types of language varieties in the community. Language contact can be direct or indirect, like if the workplace speaks the language in question, or if they only hear it through media using the internet or radio broadcasts. The role of language in sociopolitical structure can 
reflect motivations to learn the language, for example in an international business community the drive to learn English can be greater than in a rural community. The types of language varieties in the community impact SLA greatly. Tollefson provides the following examples: Unwritten languages are seldom learned in school and affect SLA processes differently from written languages. Languages without technical vocabulary may be acquired for different reasons from world scientific languages. Each language is in its own stage of development, and the priorities and tools available in the language impact the methods used to acquire them. The "language situation" in the United States at large is this: There are a large and growing number of students that need to learn English because that is the dominant language in the country, and there is a small but growing number of students that already speak English who want to learn foreign languages for economic and personal reasons.

Macro-policy goals are goals made and maintained by governing bodies. On a national level, Macro-policy goals are made by the federal government. At the state level, Macro-policy goals are made by the state government. Tollefson (1981) says that macro policy goals generally are of three types: Language maintenance or shift, structural changes in a variety, and changes in the functional distribution among varieties. Language maintenance in the United States is represented by policies that require all core k-12 content in public institutions be taught in English, in order to preserve English as the national language. Specifically in the DLI context, language maintenance is a factor that motivates programs to find and retain speakers of languages other than English, so that they may retain their first language instead of losing it in the process of becoming an English speaker. Macro-policy goals aimed 
towards structural changes could involve creating organizations that standardize modern changes in a language so that the new structure can be maintained and assessed. Functional distribution Macro-policies are exemplified in Tanzania's policies to embrace and expand use of Swahili in the country (Whiteley 1971 cited in Tollefson 1981). Macro-policy implementation is the methods or actions executed by the governing body to achieve their goals. This revolves around the allocation of resources (time, professionals, funds) to bodies that carry out the macro-policy goals. These bodies can be state education departments, university institutions, or school districts.

Micro-policy goals "require more detailed formulation of policies for local communities and individuals. These more specific policies... Involve the definition of bilingualism... (and) the nature of evaluation instruments and curriculum" (Tollefson 1981). Tollefson states that "the aim of researchers studying a particular SLA setting should be to delineate the extent to which (Swain's four variables) have been affected by planning."

There are benefits to doing an evaluative review of research in language education with Tollefson and Swain's concepts in mind. In the case of this research study, the dialogue attempts to include policy makers, language acquisition researchers, sociolinguists, and education professionals. If language acquisition researchers gather data that makes concrete the impact that schools, state education departments, and the federal government have on individual students, then more members of society become stakeholders in the language situation in the US. The main thesis of this research is to show that PPS' Dual Language Immersion Program is satisfying the needs of policies crafted to serve ELLs as well as the needs of those policies created to promote foreign 
language learning in the United States, thus yielding a very efficient educational model for all. Tollefson's model of institutional second language acquisition offers a way to organize all of the pieces to see the larger, more harmonious picture of the country's language needs. 


\section{Language Policy and DLI}

This section will provide background information on policies that have influenced the state of DLI programs today. The purpose of preceding the main argument in this research with language policy framework is to situate the data and compelling arguments from completed studies alongside the longer narrative of ELL/FLL instruction policy. This section will present ELL-based policies and FLL-based policies at the federal, state, and local levels, and then discuss some impacts on DLI.

\section{Federal Policies}

\section{Bilingual Education Act 1968}

This act is also known as Title VII of the Elementary and Secondary Education Act (ESEA). As Gloria Stewner-Manzanares states in their paper titled The Bilingual Education Act: Twenty Years Later, "The Bilingual Education Act of 1968 is noted as the first federal recognition of the needs of students with limited English-speaking ability (LESA)." The Bilingual Education Act was a very high-impact law that provided grants to institutions and school districts for the maintenance of ELL programs. The grants were given to fund the following: Resources for educational programs, training for teachers/aides, development and dissemination of materials, and parent involvement projects (Stewner-Manzanares 1988). The Bilingual Education Act of 1968 was reauthorized five times. This federal initiative began as a top-down, macro policy planning approach, and the reauthorizations of the 80 s saw a greater amount of freedom for state and local jurisdictions to engage in micro policy planning and 
implementation. By $198475 \%$ of federal funds for instruction programs were still allocated to transitional bilingual education programs (Crawford, 1987). The majority of this funding being allocated to transitional bilingual programs had a concrete impact on second language acquisition: While it was good that there was bilingual education funding, later sections show that transitional bilingual programs are not the most effective when it comes to ELL education. This macro policy had a direct effect on the input that students received for decades.

\section{Improving America's Schools Act 1994}

This law extended the Elementary and Secondary Education Act of 1965 for five more years. Title I of this Act is called "Helping Disadvantaged Children Meet High Standards", and states:

Congress declares it to be the policy of the United States that a highquality education for all individuals and a fair and equal opportunity to obtain that education are a societal good, are a moral imperative, and improve the life of every individual, because the quality of our individual lives ultimately depends on the quality of the lives of others.

This 545-page document expands the original ESEA, outlining more grants and scholarships to be made available for students and programs providing language education. The Act also outlines expectations for programs receiving funding regarding professional development and program sustainability. This Act supports not only ELLs, but it also expands financial assistance to other learners not supported in the 
mainstream public school environment, like children with developmental challenges, adult learners, migrant children, and native Americans.

\section{No Child Left Behind Act (NCLB) 2002}

NCLB was passed by former president George W Bush in 2001 in order to improve the quality of education in the US across the board in the face of lower performance numbers in math, English language arts and science when compared to our international peers. The first three titles characterize this Act: Improving the Academic Achievement of the Disadvantaged; Preparing, Training and Recruiting High-Quality Teachers and Principals; Language Instruction for Limited English Proficient and Immigrant Students (Title III §3102). Although the law was passed with bipartisan support at the time, it created a lot of hardship for educators because when students didn't meet assessment standards, there were punitive measures taken out against the schools (Menken 2010). This system was especially harsh on schools with many ELL students, where they were tested against the same standards as their native Englishspeaking peers- diminishing the results of the schools and discounting the learning and

progress made by the ELLs (20 USC $\S 1111$ (A) (b)). Because of this, in 2012 President Barack Obama began granting leniency on some elements of NCLB when "rigorous and comprehensive state-developed plans" were proposed in exchange. 


\section{ESSA 2015}

This act, passed by Congress in 2015, extended (yet again) and expanded the Elementary and Secondary Education Act of 1965. It requires for the first time by law that students "are taught to high learning standards aligned with college coursework entry requirements and state career and technical education standards." In the section titled "Equity for Native Youth", the Act created entities to help Native tribes preserve their endangered languages by creating school programs that maintain the languages. ESSA amended 20 USC Title III (regarding ELLS) by expanding grants and changing some definitions: i.e., "limited English-proficient" is replaced by "English learners", and appropriations were extended for five more years.

\section{HR 5764: "The SYLLABLE Act”}

"This bill authorizes the Department of Education to award up to five grants to partnerships of local educational agencies, early childhood education programs, and technical assistance entities for the implementation of dual language immersion programs designed to enhance and assess the biliteracy and bilingualism skills of low-income children, including English learners and minority children, in high-need schools from preschool through grade five." (Congress.gov)

The bill proposed in 2020 by members of Congress starts with this statement, among others: "Studies have demonstrated that all students in dual language immersion 
programs have higher academic achievement as measured by statewide examination, regardless of socioeconomic status."

The bill has not yet been brought to vote in the house of representatives, it was first introduced in February, 2020 and feasibly had been postponed due to the COVID19 pandemic. Those in the education community at large have reason to be excited about this piece of legislation. Were it to pass, DLI specifically would be given financial support in many more school districts across the country, which would have an incredibly positive effect on SLA and also would push the needle in the right direction with regard to changing academic outcomes for linguistically repressed students.

\section{HR 2562: Advancing International and Foreign Language Education Act (2019)}

Primarily proposed as a reauthorization of Title VI of the Higher Education Act of 1965.

Section 605: International Research and Innovation outlines grants available for private or public nonprofit institutions to administer foreign language/ area studies programs, as well as for such institutions that seek to investigate the national availability of such programs, their results, and gaps in program availability where the need is actually considerable.

"It is the purpose of this section to support essential international and foreign language education research and innovation projects with the goal of assessing and strengthening international education capacity, coordination, delivery, and outcomes to meet national needs."

Introduced in 2019 and still awaiting committee approval and house vote. 


\section{National Security Education Program}

NSEP's mission statement: "At NSEP, our primary mission is to develop a pipeline of foreign language and culture expertise for the U.S. federal government workforce." NSEP was established by the David L. Boren National Security Education Act of 1991 (U.S. Code 50, 90 et seq.), a bill proposed by former Senator Boren and signed into law by President George Bush in 1991. This Act required that the Secretary of Defense award funding to undergraduate students for study abroad opportunities, graduate students for language/area fellowship studies, and institutions for the establishment of language/area study programs. This program, brought to life through language policy, has been changing the SLA game for thirty years when it comes to foreign language acquisition. Many language departments in universities across the country are able to thrive and offer study abroad programs to students of diverse socioeconomic backgrounds, truly creating a "pipeline" of available foreign language and culture expertise out of our college students. In terms of adult foreign language acquisition, study abroad is the \#1 most effective route to developing lasting language competency. Study abroad as a tool provides an extraordinary amount of naturally occurring language input for students, something that Tollefson, Swain and most others in the SLA community say are vitally important for language acquisition (See Swain 1979). Not only does study abroad provide input, it creates situations where students are under pressure to produce target language. Often the students are pushing the boundaries of 
what they know with empathetic native speaking listeners, which results in the students actively crossing the threshold into the "zone of proximal development" (Vygotsky 1978), a concept where students learn best when they are building upon their knowledge meaningfully with a more knowledgeable partner.

\section{$\underline{\text { State Policies }}$}

\section{ORS 336.079- English Language Learners}

This Oregon state statute establishes a requirement for ELLs to have access to quality English language education from grades $\mathrm{k}-12$. Access to said instruction is only required for students until they are deemed ready to attend normal English-delivery coursework. Additionally this statute lays groundwork for state intervention in school districts where districts report (as required annually by ORS 327.016) ELL students not meeting benchmarks established by the Oregon Department of Education. The statute calls for four years of technical support at the school district level from ODE, and if after four years the ELL population is still not achieving benchmark scores then ODE shall determine how the district appropriates funds granted by the state.

\section{ORS 327.345- Grants for Training ELL teachers}

This Oregon State statute provides for training of ELL teachers in at-need districts, which includes schools in which $3 \%$ or more of students classify as ELL students, 
schools where the population of ELL students has increased dramatically in a small amount of time, and schools that serve diverse students in a wide geographical area. https://www.oregonlaws.org/ors/327.345

\section{Impact}

The Acts listed above represent just some of the work done at the government level to support English language learners in the United States. Each one of these pieces of legislation has impacted events in classrooms: lessons created and implemented, resources made available to students and teachers alike, and the pedagogical / sociolinguistic philosophies that impact the structure and goals of ELL education. There have been many victories for ELLs that have come about from language planning and policy. As the citizens of the United States collectively move into the future, improving language learning goals from the top down can transform Tollefson's "Language Situation Variables": Multilingualism can become the norm, as it is in Europe, Africa, Asia and much of the rest of the world. The consequences of an American language infrastructure that improves SLA and expands access to multiple languages for everyone will be felt by everyone, and most importantly by those that have been hamstrung by an education system that favors English speakers. Policy makers in coordination with educators have a chance to change academic outcomes through language. As we will see in the next two sections, it is the opinion of this research paper that Dual Language Immersion programs are the ideal way of closing the academic achievement gap for ELLs and promoting foreign language learning for native speakers of English. 


\section{Portland Public Schools' Dual Language Immersion Program in Portland, Oregon}

In Portland, Oregon, there is a supplemental bilingual education program called Dual Language Immersion. This program, operated by the Portland Public Schools (PPS) school district, offers two-way immersive language studies as a part of the k-12 experience. The anchor language in the program is English, and the "partner language" is one of the following options: Mandarin, Japanese, Spanish, Vietnamese, or Russian. Operating in as many as $25 \%$ of Portland public schools, the program in PPS has been delivering high quality immersion education for over thirty years (PPS DLI website). This section will explain the program strategy, cover the admissions process, and touch on the instructional style and assessment as presented by PPS. It will also consider the many stakeholders in $\mathrm{DLI}$, and end by comparing the program to monolingual and other bilingual programs.

The DLI program follows a "two-way immersion" model, and a "one-way immersion" model. Two-way indicates that the students attending the bilingual program are (ideally) native speakers of one of the languages or the other. While classes at the school are administered in either English or the partner language (one of the five above), the two groups of students from different linguistic situations will be learning their native language and the partner language. One-way indicates that the students attending the bilingual program are mostly native speakers of one language and they are working together to learn a second language. The languages that utilize the oneway model are Chinese, Japanese and Vietnamese. There are many benefits to this 
system: Linguistically, students are getting access to their L1 while also developing an L2, which benefits them academically (core subjects are taught in both languages), and the students benefit as people as they learn in a multicultural environment that doesn't favor one or the other. More time will be devoted later to research supporting the position that this model is an excellent education model for both English language learners and native speakers of English. The DLI program is iterated in two different ways: What PPS calls "90/10" (for two-way immersion) and " $50 / 50$ " (utilized by the oneway model). The $90 / 10$ model starts at $90 \%$ instruction time in the partner language and $10 \%$ instruction time in English. This changes 10\% in the other direction with each passing year, ending fifth grade at $50 \%$ instruction time in each language, and decreasing eventually to $20 \% / 80 \%$ in high school. In this way, students are maximally exposed to the target language in their younger years; a time that research indicates is the optimal time to learn languages (Snow and Hoefnagel-Höhle 1978, DeKeyser 2000). This is ideal because it is very likely that students in the US will be exposed primarily to English as they finish school and begin working, so the instructional time in English should ramp up as they get older and are about to embark on greater challenges where the language is required. With less exposure to the partner language as the students get older, they deserve the early-years advantage, to best promote equal competence in both languages. The 50/50 model is the same concept, except the exposure to the language favors more English instruction time. In elementary school, the students spend $50 \%$ of instruction time in both languages, middle school increases the English to a rate of $33 \% / 67 \%$, and high school sees the rate of $20 \% / 80 \%$ as in the other model. 
PPS DLI program has a very specific mission - to help close the academic achievement gap between white native speakers of English and Lx learners of English that come from diverse backgrounds. In an interview conducted as part of research for this paper, a senior member of the program said that the main drive behind the program was student equity: The mission is to create an environment of linguistic equity where a student's cultural and linguistic assets are nurtured and encouraged, which will ultimately lead to changing academic outcomes for population segments that are traditionally linguistically limited in US public schools. The need is very great: the interviewee also noted that $20 \%$ of incoming kindergarteners are enrolling in $\mathrm{DLI}$, and there has been a dramatic increase in program demand in the last 10-12 years. This belief in the need for equity for all students impacts the system through which students are admitted to the school. The students are admitted through a lottery, which evens the playing field for all applicants. The school district prioritizes students who speak the partner language as a heritage language, with preference given to those that live in the neighborhoods near the schools. There are also spots for native speakers of English, with preference given to local students. The lottery for admission occurs annually, and lottery slots are intentionally designated to the highest need groups first. (Steele, Slater et. al. 2015 p.12)

The instructional practice is intentionally designed with language teaching pedagogy engaged. The instructors communicate with the students only in the designated language for the duration of the class. They also teach in "a comprehensible way so that students with limited proficiency in a language are able to understand the teacher through gestures, body language and effective strategies while students gain 
proficiency in the language" (PPS Website). In the RAND Foundation study of Portland's DLI program, Steele et al. observe in a study of 119 forty-five minute classes in 2014 that language of instruction in DLI classrooms was consistent with the program guidelines for each grade level (Steel et al 2015, p.12). The students are given partnerlanguage instruction in mathematics, language arts, science and social studies throughout Elementary school, and then in middle school the content is gradually taken over by English instruction. In high school, the only partner language instruction is in the form of advanced language classes (Steele et al 2015). At each level, the students are assessed using the same standardized tests administered by the state for all students, immersion or not. For more of the data on how the immersion students compare see the section in this study titled "Data and Research". The students are assessed not only on their core academic content, but also on their relevant language competencies. ELLS are assessed on their English each year, and these tests, called the English Language Proficiency Assessment (Oregon Dept. of Ed., ELPA), are important evaluations of the students and of the program because students that meet certain criteria are no longer considered ELLs. ELL students that successfully lose their ELL status are a very important success metric in the program.

There are many stakeholders in the Portland Public School Dual Language Immersion Program. Stakeholders are the people that are invested in the success of the program; they are those members of the population that benefit from its existence and its improvement. The students clearly have the most to gain from the program, and among the students, those that speak the partner language as a native language are the students that stand to gain the most. Research shows that the students that excel 
ahead of their non-immersion peers are the students that get instruction in their native language as well as in English. These students are six percentage points less likely to still be classified as an ELL by the fifth grade (Steele et al p. 24). Additionally, the RAND Foundation study also points out that "one rationale for placing ELL students in-two-way immersion programs rather than transitional bilingual classes is that two-way immersion integrates them with native English speakers while also supporting their native language development" (Collier \& Thomas, 2004). Not only do those students benefit from the program, but their families benefit as well. In the case of Heritage learners, parents often play the largest role in their children maintaining their heritage language (Park \& Sarkar 2007). DLI offers an opportunity for families to preserve their heritage, strengthen relationships and preserve culture while also cultivating the English skills to help them find stability in an English-dominant culture. This holistic approach to heritage learner education can spill over into the whole family in many ways. L1 Partnerlanguage speakers aside, the native English-speaking students that successfully complete Portland's dual language immersion program stand to gain cultural sensitivity, out-group empathy, enhanced cognitive and academic ability, and bilingualism (Collier and Thomas 2004, p.11). The research data in the following sections will reiterate this position, but entrance to this program is competitive for those reasons. When an observer considers that the DLI program shows preference for local students, native English-speaking Portlanders also gain a lot of value from the preservation, improvement and expansion of Dual Language Immersion; increased access grants more educational opportunities for students that want to pursue careers that require or are enhanced by multilingualism. The student group that sees slightly diminished value 
from DLI is the group that speaks neither English nor the partner language as an L1 (Steele et al. 2015). This is solely because students that speak a language at home different from either language in school are pushed to learn two languages from scratch, and they have potentially no help from home with either of the school languages. However, the diminishing value pertains therefore just to additional language resources, and potential cognitive strain. Children have shown to be capable of learning two or more languages at once (Muñoz 2010). These students still benefit from being a part of a harmonious, multicultural classroom community, and they still gain all of the benefits of multilingualism that come with participation in the program. Another significant stakeholder in the program is government at all levels. Programs that develop bilingual, high-achieving students will provide a great return on investment when they join the workforce and fill government positions that require intercultural competence and multilingualism (Gandára \& Acevedo 2016). One could argue that society at large is a stakeholder in PPS' DLI program. The last topic covered in this explanation of the twoway Dual Language Immersion Program in PPS is a comparison of DLI to other programs that aim to serve L1 speakers of languages other than English.

The main resource available in most communities is monolingual English as a Second Language instruction (ESL). ESL is available in many k-12 school districts, Portland included. In an ESL classroom the students are taking on extra class hours after school, or incorporating classes during the school day (which takes them away from other academic content their L1 English-speaking peers are learning). There are a couple disadvantages of monolingual ESL over DLI. Monolingual ESL is an additional burden on students' schedules, especially since they are still held to the same core 
academic content standards as L1 English speakers. This puts the students behind just from a scheduling standpoint (Collier and Thomas 2004). ESL classrooms also often lack the ability to expose students to communicative exercises with L1 speakers of English, something that is shown to benefit Lx language learners: See the difference between bilingual programs, English Immersion, and DLI in Valentino and Reardon 2015. Proponents of monolingual immersion in English have argued that it is not the job of school districts and bodies of government to maintain peoples' heritage languages, and that concentrated exposure to just English is most crucial for their adaptation to life in the US. Both points are opposed in this paper. First, if the government is going to subject all students to the same core standardized testing (see "No Child Left Behind" in SLA policy section), which impacts their access to further education and training, and financial stability overall, it is unjust to use English as a way of gatekeeping these resources. Because students have been subjected to English-only education, as discussed above, they have fallen behind their English-speaking peers time and again, through no lack of effort on their part. The Civil Rights Act of 1964 (also in the coming section on SLA policy) states that all children in the United States should have equal access to education, which implies that the nation cannot justly ignore the language situation of all students that don't speak English as a first language. Second, saying that English is the end-all-be-all of language in the United States does not reflect reality in the United States. Statistically speaking, the United States Census Bureau estimates that just over $22 \%$ of households in the US speak a language other than English at home. Estimates for Oregon are at $15 \%$, Washington is approximately $20 \%$, and California boasts a whopping $44 \%$ of households speaking a language other than 
English at home (US Census Bureau). There are an incredible amount of households just on the west coast where English is not the only language spoken in the home, and saying English is the priority reflects more of a political agenda than reality. ESL is a very important resource, especially for adults that need urgent English education, but it is the position of this paper that as a society we can do better for our children that come from an increasingly common, diverse language situation.

Aside from ESL, there are also transitional bilingual (TB) immersion programs all over the US. Transitional bilingual programs "serve only ELLs, separate from their nonELL peers." (Valentino \& Reardon, 2015). Transitional bilingual programs move to English-only immersion during the elementary school years, and the goal is not to develop bilingualism, but to wean the students off of their L1 and make them fully competent in English. This program has the same language attitude as Monolingual English immersion: The student's L1 is a problem that needs to be rectified, instead of an asset that should be developed. The first glaring disadvantage that transitional bilingual programs have compared to DLI is the classroom composition. ELL students have only their instructor to receive input from in TB, so their learning is more like an immersive foreign language course. Especially in elementary schools, families would have to have additional resources to increase exposure to English. Keeping a group of ELLs separate from their English-speaking peers hinders their English growth. Compare that classroom to a DLI classroom, where the goal is to have a mixed classroom- the ELLs are learning English with and from the native English speaking students as well as the teacher. Not only do the ELLs get more effective English input exposure, they also continue to develop their heritage linguistic assets, which also helps the native English 
speakers achieve their L2 goals. Not only do the students in the transitional bilingual programs receive objectively worse English exposure, they also don't get enough time to develop their L1, since the instruction in their home language stops by third or fourth grade. This reduces their chances for overall academic literacy in their L1, effectively putting that burden on their families. A longitudinal study by Thomas and Collier (2002) found that students in DLI programs had more positive academic outcomes than students enrolled in transitional bilingual programs in Houston, Texas, where many students enrolled in Houston Independent School District are of hispanic heritage. The next segment will describe in more detail the results of previous studies surrounding DLI.

\section{Research and Data}

This section will present data from and conclusions drawn by researchers Thomas and Collier (2002,2004), Valentino and Reardon (2015), and Steele, Slater et al (2015), to provide evidence for the claim made in this paper that DLI stands out as the best program moving forward to combat the academic achievement gap for ELLs, promote effective FLL for native-English-speaking students, and even promote greater academic achievement for both populations through the cognitive benefits of the model.

Steele, Slater et al (2015) 
The name of the preliminary paper presenting data from Portland Public School's DLI program is: The Effect of Dual Language Immersion on Student Achievement: Evidence from Lottery Data. Representatives from many different organizations and research entities collaborated on this research: the RAND Corporation, American Councils for International Education, American University, University of Arkansas, and Portland Public Schools. This study is exceptional due to the fact that it "examines the general academic (achievement) effects of immersion education on native speakers as well as ELLs in the United States, and does so longitudinally between kindergarten and eighth grade." Utilizing a lottery-based system, test score data was collected from students randomly assigned to DLI across all 20 participating immersion schools, in one-way or two-way immersion, and also from students that were not enrolled in PPS' DLI. Data was collected on students that applied to the PPS' DLI program between the years 2004-2010, for a total of seven "cohorts".

Here are some of the takeaways from the results of the study:

- Lottery winners (students enrolled in PPS' DLI) are 3-4\% less likely to be classified as ELLs in sixth and seventh grade, and estimates are larger for students whose native language matches the partner language $(14 \%)$.

- The study finds that students randomly assigned to immersion in kindergarten outperform their counterparts in fifth grade reading by $13 \%$ of a standard deviation, and in eighth grade by more than $20 \%$ 
- Eighth grade students assessed on partner-language proficiency in Spanish and Chinese reach intermediate-mid-level proficiency; students in Japanese reached intermediate-low-level proficiency.

- Effects of participation in the program on mathematics and science appear positive but are indistinguishable from zero in most cases. Click here for more.

In addition to the above bullet points, the study also found that the metrics of success were similar regardless of the student's native language, indicating that the benefits of dual language immersion are for all students; not just for students whose native language matches either the partner language or English. Not only are all students benefiting from the program independent of their particular language situation, the report also states that both time and financial resources dedicated to the DLI program are not significantly different from the mainstream school district costs: further financial information is included in the reports found on the Portland Public Schools website. The results of this study further solidify the conviction in this paper that DLI is a breakthrough approach to public school education, and further studies (Valentino \& Reardon 2015, Thomas \& Collier 2002, 2004) were analyzed to see if the results of the PPS study were further supported by the discourse community of educators and SLA researchers. 


\section{Valentino and Reardon, 2015}

This study by Rachel Valentino and Sean Reardon of Stanford University Graduate School of Education compares academic achievement metrics of four different public school programs (in one school district) designed to serve English language learners: Monolingual English immersion (EI), transitional bilingual (TB), developmental bilingual (DB), and dual immersion (DI). The study finds generally that students in TB and DI programs outperform their El peers in English language arts. The Valentino and Reardon study disaggregates results by ethnicity, which enters a topic 
not covered by this paper. However, some promising results are discovered in the study regarding English language arts scores from grades 2-7:
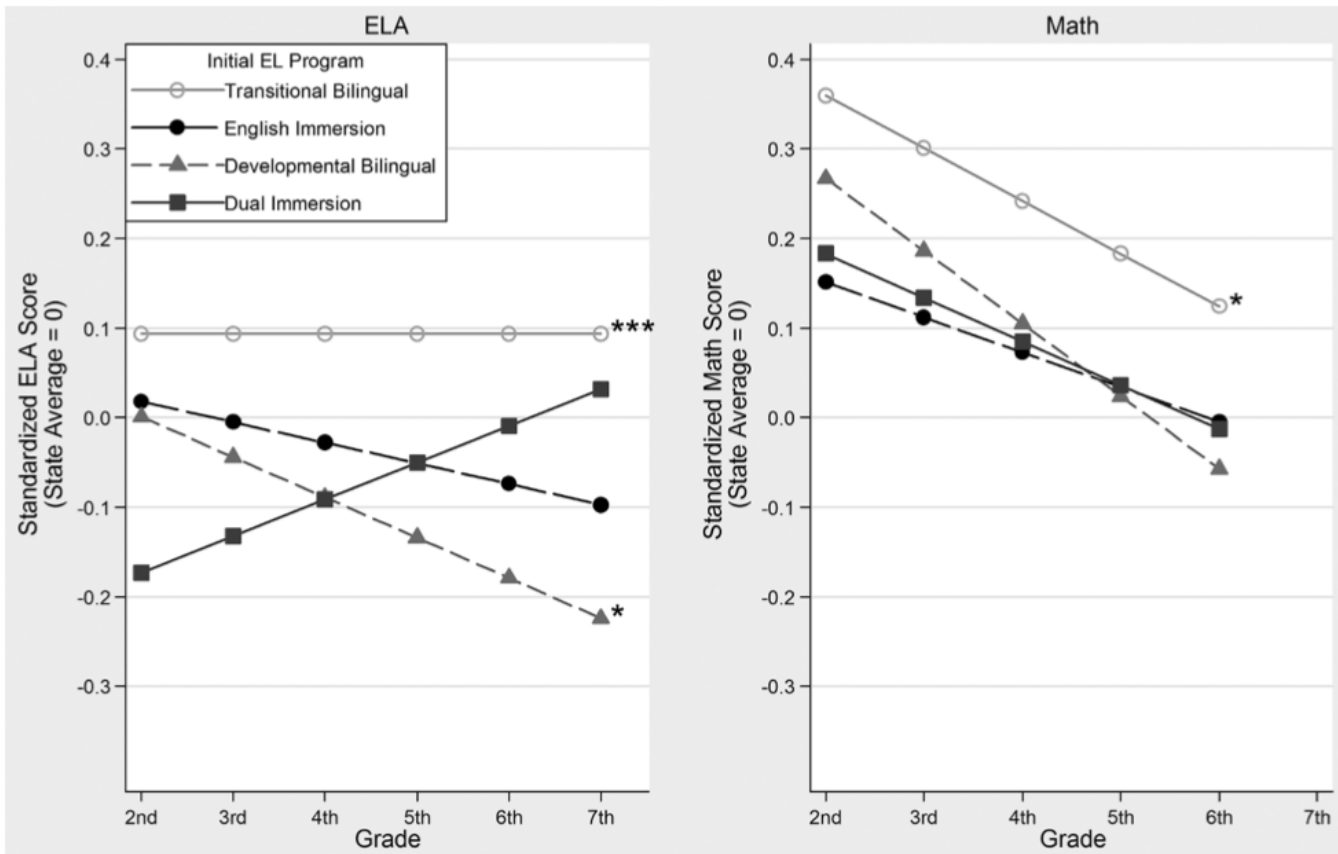

FIGURE 1. Estimated average ELA and math achievement trajectories, relative to state average: EL kindergarten entrants, by instructional program

Note. The figure is based on the estimates from Model 4 in Table 3. We performed the tests of significant differences across programs in the final grade of evaluation. Asterisks indicate that the average seventh (ELA) or sixth (math) grade outcome is significantly different from that among those whose initial EL program was English immersion. ELA = English language arts; $\mathrm{EL}=$ English learner. ${ }^{\dagger} p<.10 .{ }^{*} p<.05 .{ }^{* *} p<.01 .{ }^{* * *} p<.001$.

Valentino and Reardon, 2015, pg. 626 
The graph on the left indicates that although ELL students enrolled in DLI enter second grade with below-average English language arts skills, they quickly catch up and are among the best-performing students in English-related skills by the seventh grade. The only group that outperforms them is the transitional bilingual group, but one could project that the DLI students overtake even them in English by high school, and the transitional bilingual students likely stopped learning in their native language by the third grade. The study also finds that DB program participants fared worse in English language arts development than their El counterparts. One weakness of this research for the sake of this study is that there appeared to be no data collected on the impact $\mathrm{DI} / \mathrm{DLI}$ had on native-english-speaking participants. This is because the study is really about the program causal effects on ELLs.

\section{Collier and Thomas 2002, 2004}

Virginia Collier and Wayne Thomas published a study (2002) on DLI students in the Houston Independent School District (ISD), a district with over 210,000 students. The study reports that $54 \%$ of the students in the ISD were from Spanish-speaking households. The study was done on 1st-5th grade students from 1996-2001, and the data collected was test results on English and Spanish reading proficiency for ELLs. Their data shows that ELL students in two-way bilingual immersion (DLI) exceeded their 
transitional/developmental bilingual program peers in both Spanish and English reading by the fifth grade- never being exceeded in any one year by samples from the other programs (See Collier and Thomas 2004 for figures). The ELL students in the DLI programs far exceeded their non-DLI peers on English proficiency in each year: "ELLs in the two-way classes outscored ELLs in the other two bilingual programs by 7 Normal Curve Equivalents (NCEs) or more, a very statistically significant difference" (Collier and Thomas 2004). Included in the same publication is a study of heritage learners of French in Maine, near the Canadian border. The study begin in 1996 with 101 students in Dual-language immersion and 59 students in English-only immersion, and only tested on English reading achievement by grade (1-5): Starting at the same baseline, students in the DLI program annually improved their scores on the "Terra Nova in English Reading" exam at a rate of 3:1 when compared to their English-only peers. With both groups sharing a baseline in the 40th NCE, the DLI students were scoring in the 62nd NCE by the fifth grade; their English-only peers scored in the 48th NCE by the fifth grade. Collier and Thomas not only conducted these studies that showed that ELLs in DLI programs learn English at an astonishing rate, they also collected data for different types of bilingual programs: transitional and developmental bilingual, and 90:10 and 50:50 two-way (DLI). Their data shows that two-way, well-implemented 90:10 immersion can be expected to close $95-100 \%$ of the English-language gap for ELLs by the fifth grade. The other bilingual courses carry a much lower minimum threshold by their calculations- $70 \%$ of the language-gap reduction can be expected by the fifth grade. In their 2002 study, Collier and Thomas found that native English speakers also experienced higher levels of achievement across the board: 
"Native-English speakers in two-way bilingual immersion programs maintained their

English, added a second language.. And achieved well above the 50th percentile in all subject areas on norm-referenced tests in English... Equalling or outperforming monolingual comparison groups on all measures" (Collier and Thomas 2002, p. 310).

\section{Synthesis of results}

These studies are just a few among many that objectively indicate that DLI (specifically two-way 90:10 immersion) has significant potential to revolutionize second language acquisition in the United States, close the achievement gap for ELLs, and increase test scores on national standardized assessments across the country.

\section{Closing the Achievement Gap:}

Valentino and Reardon postulate two main reasons for DLI students having accelerated success in English, both of which were described earlier in the paper: First, ELLs in DLI programs are in courses with their native-English-speaking peers, which increases their exposure to model language use throughout the entire program. The second reason is that some research (Cummins, 1979, 2000; Genesee et al., 2008) has found evidence that "languages share core underlying structures that require similar proficiency skills" (Valentino and Reardon 2015), and students proficient in their home language develop the core academic skills required to help them learn English more effectively: skills in learning strategies, critical thinking, basic reading and writing concepts, and science. The data from Collier and Thomas showed that students being in peer groups that contained half partner language speakers and half English speakers 
resulted in the greatest annual gains in language skills for both English and the partner language. The Steele, Slater et al. study shows that learners in DLI programs are both less likely to be classified as ELLs in middle school as their peers in other programs, and also more successful on state reading and writing tests. These findings unanimously support the claim that the $90: 10$ two-way immersion structure is the most effective for closing the achievement gap between native-English-speaking students and students that are ELLs: Through building a strong foundation of core content knowledge in their L1, promoting their fluency and mastery over their home language, using that language foundation to fuel their English acquisition, and providing them with peers that can provide abundant model language in English.

\section{Effective FLL for Native-English-speakers:}

While not as important as reducing the achievement gap between ELLs and native-English speakers, pointing out the many benefits of DLI for L1 English speakers is an important step (regarding Language Planning and Policy) towards creating broad support for the programs. Documenting the many benefits of DLI for the majority English speaking population can push the needle in the direction of supporting DLI in communities where ELL need is only a small sample of the student demographic: Yes, Dual Language Immersion is the best program for the ELLs in the area, and it's also a valuable community asset for everyone. From an FLL standpoint, Steele, Slater et al found that students tested in the partner language in middle school reached a low-tohigh intermediate proficiency level. This is an astounding achievement and an asset only otherwise attained by those students that grow up in an L2 environment and speak 
English at home, for instance if a student from an English-speaking family is growing up and attending school in a Chinese province. DLI L1 English speaking students learn core content first in their L2 and then in English (in most cases). They have a peer group of students that can provide the same valuable model language. The apparent benefit for FLLs also ties into the next section: the fact that academic achievement in all areas seems to be positively impacted by the program, showing that FLLs stand only to gain biliteracy and heightened academic achievement.

\section{Broadly-enhanced Academic Achievement:}

"The present knowledge base demonstrates that DLI programs lead to positive achievement outcomes for both language-minority and language majority students, especially for young children developing fundamental language and literacy skills" (García and Náñez 2011). The findings of all three above research studies state that students in DLI - both L1 English speakers and L2 English speakers- consistently match or outperform their peers on standardized tests in English language arts, mathematics and the sciences. The academic achievement enhancement for ELLs is clear: the program teaches and tests L2 speakers of English equitably by providing them instruction on core content in their first language. Especially with the 90:10 format, their first language is an academic asset for them, instead of something to be repressed or expunged in favor of English. This, along with the unparalleled effectiveness of their English learning, creates an environment where ELLs are given the tools to succeed on all national education standard requirements. Furthermore, Collier and Thomas, utilizing one of the largest research databases of student records assembled for DLI studies, have found that L1 English speakers also have a greater academic achievement 
average than their peers in English-only schools. There are some benefits for all learners in this program that are outside of the language experience. Students are taught in an inclusive, collaborative environment that fosters intercultural exchange and friendship building. The benefits of a concerted approach to cohesion are affective, psychological, and social. Collier and Thomas in their 2004 report interviewed many parents, teachers and administrators and found that the experience of DLI felt like the most rewarding educational environment they had ever worked in, and these benefits touch the lives of the students and the community.

\section{Future research}

Each of the above reports calls for additional research on the efficacy and impact of DLI. Broadly, more longitudinal studies with a greater abundance of study participants are needed, so researchers can more effectively gauge effects of DLI on students from different backgrounds. There needs to be more studies on the effects of DLI on academic outcomes for students from a broader range of disadvantaged backgrounds: Students in impoverished communities, students from rural vs. urban communities, accounts of effectiveness per ethnic background, studies of DLI effects on students with learning challenges, physical challenges, and more. There is also another factor that needs to be teased out of DLI research: The impact of parental involvement in the students' education. In Steele, Slater et al, the researchers acknowledge that all of the participants in the DLI program have parents that want their students to be successful academically, which skews their academic achievement data when trying to compare them to students enrolled in monolingual English public schools- the percentage of 
highly invested, involved parents is higher in DLI program participants by default, which can have a tremendous impact on student achievement in all subject areas. Therefore, studies that account or adjust for this factor are needed: Maybe developing a study where the monolingual data compared against the DLI sample comes from students enrolled in exclusive private schools. It will also be necessary to lead in-depth studies on students that speak neither the partner language nor English as a first language. This is an important area to collect data on, because there will be many students in school districts where providing core content instruction in their first language is unfeasible- the resources are too scarce and qualified instructors may be unavailable. So ensuring that these students do still benefit from DLI is important, or otherwise determining the path to success for them; these students are every bit as important in our race to close the achievement gap among all students. Additional qualitative data should also be gathered regarding the effect of DLI on communities where they are located, through surveys and interviews of faculty, students, parents, and community members that employ these local students or otherwise interact with them. This vein of research could be challenging, but positive results could further encourage future investment.

\section{Conclusion}

This study set out to unite the communities of Second Language Acquisition researchers, educators, policymakers and policy experts behind the efforts of many communities across the United States: The effort to use Dual Language Immersion to eliminate the achievement gap between ELLs and L1 English speakers, while also 
creating a program that drastically improves learning outcomes for all. This study showed: How second language acquisition is impacted just as heavily by the nation's language plans and policies as it is by classroom instruction, which policies have influenced the linguistic and education landscape from the 1960s to now, how Dual Language Immersion is operated by the Portland Public School District, how research has shown that DLI is the optimal program for success measurements of English, bilingualism, and overall academic achievement.

Second language acquisition includes not just matters of what is presented in the classroom, but also how the nation's leaders prioritize language instruction, and all of the intermediary actors. The United States has to agree on a language plan for the future: will it continue to push a monolingual, English-as-power agenda on students that perpetuates generational achievement gaps? Or will it become more inclusive, and offer multiple avenues for all citizens to become the best they can be? The position crafted in this study is that Dual Language Immersion is a viable language plan going forward for many reasons. This study calls for education and language policy makers to put DLI on their radar, if not their immediate agenda. Macro implementation of DLI initiatives could wield a large influence over the implementation of DLI at the micro (community) level, which would change the linguistic situation in the US: No more under-achievement just because of ELL classification, no more shortage of bilingual civil servants, no more dismal acquisition rates of foreign language fluency in the US, and hopefully no more English-based discrimination in classrooms, businesses, government agencies, and public health services. DLI can be instrumental in laying a strong foundation for the United States as we move into the future. 


\section{References}

Bialystok, E. (2007). Cognitive Effects of Bilingualism: How Linguistic Experience Leads to Cognitive Change. International Journal of Bilingual Education and Bilingualism, 10(3), 210-223. https://doi.org/10.2167/beb441.0

Bilingual Education Act of 1968, Pub. L. No. 90-247, 81 stat. 816.

Thomas, W. P., \& Collier, V. P. (2002) .A national study of school effectiveness for language minority students' long-term academic achievement.

Collier, V. P., \& Thomas, W. P. (2004). The Astounding Effectiveness of Dual Language Education for All.

Crawford, J. (1987). Bilingual Education: Language, Learning and Politics. A Special Report. Education Week.

Cummins, J. (1979). Linguistic interdependence and the educational development of bilingual children. Review of educational research, 49(2), 222-251.

Cummins, J. (2000). Language, power, and pedagogy: Bilingual children in the crossfire (Vol. 23). Multilingual Matters.

David L. Boren National Security Education Act of 1991, Pub. L. No. 102-183

DeKeyser, R. M. (2000). The robustness of critical period effects in second language acquisition. Studies in second language acquisition, 22(4), 499-533.

Esposito, A. G., \& Baker-Ward, L. (2013). Dual-Language Education for Low-Income Children: Preliminary Evidence of Benefits for Executive Function. Bilingual Research Journal, 36(3), 295-310.

https://doi.org/10.1080/15235882.2013.837848 
Every Student Succeeds Act of 2015. Pub. L. No. 114-95.

Gandára, P., \& Acevedo, S. (2016). Realizing the economic advantages of a multilingual workforce. UCLA Civil Rights Project. Retrieved on December, 18, 2016.

García, E. E., \& Náñez, J. E. (2011). Best practices and successful strategies. In E. E. García \& J. E. Náñez, Bilingualism and cognition: Informing research, pedagogy, and policy. (pp. 131-156). American Psychological Association. https://doi.org/10.1037/12324-007

Genesee, F., \& Jared, D. (2008). Literacy development in early French immersion programs. Canadian Psychology/Psychologie canadienne, 49(2), 140.

H.R. 2562 "Advancing International and Foreign Education Act", 116th Cong. (20192020).

H.R. 5764 "The SYLLABLE Act”, 116th Cong. (2019-2020)

Improving America's Schools Act of 1994. Pub. L. No. 103-382, 108 stat. 3518.

Krashen, S. D. (1976). Formal and informal linguistic environments in language acquisition and language learning. Tesol Quarterly, 157-168.

Krashen, S. (1978). Individual variation in the use of the monitor. Second language acquisition research: Issues and implications, 175-183.

Menken, K. (2010). NCLB and English language learners: Challenges and consequences. Theory Into Practice, 49(2), 121-128.

Muñoz, C. (2010). On how age affects foreign language learning. Advances in research on language acquisition and teaching, 39-49. 
No Child Left Behind Act of 2001, Pub. L. No. 107-110, 30 Stat. 750 et al.

Oregon Dept. of Education. (n.d.). English Language Proficiency Assessment. Retrieved May 12, 2021.

ORS $327 \S 345$ Grants for training English language learner teachers, 75th Oregon Leg., 2009.

ORS 336 § 079 English Language Learners, 78th Oregon Leg., 2015.

Park, S. M., \& Sarkar, M. (2007). Parents' attitudes toward heritage language maintenance for their children and their efforts to help their children maintain the heritage language: A case study of Korean-Canadian immigrants. Language, culture and curriculum, 20(3), 223-235.

Portland Public School District. Department of Dual Language Immersion. https://www.pps.net/Domain/85, Retrieved May 12th, 2021.

Reardon, S. F., \& Galindo, C. (2009). The Hispanic-White Achievement Gap in Math and Reading in the Elementary Grades. American Educational Research Journal, 46(3), 853-891. https://doi.org/10.3102/0002831209333184

Snow, C. E., \& Hoefnagel-Höhle, M. (1978). The critical period for language acquisition: Evidence from second language learning. Child development, 1114-1128.

Stewner-Manzanares, G. (1988). The Bilingual Education Act: Twenty Years Later. New Focus, Occasional Papers in Bilingual Education, Number 6. New focus. Sutcher, L., Darling-Hammond, L., \& Carver-Thomas, D. (2019). Understanding teacher shortages: An analysis of teacher supply and demand in the United 
States. Education Policy Analysis Archives, 27, 35. https://doi.org/10.14507/epaa.27.3696

Steele, J. L., Slater, R., Zamarro, G., Miller, T., Li, J., Burkhauser, S., \& Bacon, M. (2015). Effects of dual-language immersion on students' academic performance.

Tollefson, J. W. (1981). THE ROLE OF LANGUAGE PLANNING IN SECOND LANGUAGE ACQUISITION. Language Learning, 31(2), 337-348. https://doi.org/10.1111/j.1467-1770.1981.tb01388.x

United States Census Bureau (n.d.). United States of America. https://data.census.gov/cedsci/profile?q=United\%20States\&g=0100000US Valentino, R. A., \& Reardon, S. F. (2015). Effectiveness of Four Instructional Programs Designed to Serve English Learners: Variation by Ethnicity and Initial English Proficiency. Educational Evaluation and Policy Analysis, 37(4), 612-637. https://doi.org/10.3102/0162373715573310 Whiteley, W. H. (1971). 7. SOME FACTORS INFLUENCING LANGUAGE POLICIES IN EASTERN AFRICA. Can Language Be Planned?, 136. 


\section{Appendix}

\section{की Portland State}

Human Research Protection Program

$1600 \mathrm{SW} 4^{\text {th }}$ Avenue, Suite 620

Portland, OR 97201

(503) 725-5484 psuirb@pdx.edu

\section{Human Research Protection Program \\ Notice of Exempt Certification}

January 29, 2021

Dear Investigator

The PSU Institutional Review Board (IRB) reviewed the following submission:

\begin{tabular}{|l|l|}
\hline Investigator(s) & Kimberley Brown / Andrew MacLean \\
\hline HRPP \# & $217164-18$ \\
\hline Title & $\begin{array}{l}\text { High-Stakes Education: A Dual-Language Immersion Programs in Portland, } \\
\text { Oregon }\end{array}$ \\
\hline Funding Agency / Kuali \# & N/A \\
\hline Determination Date & January 29, 2021 \\
\hline Expiration Date & N/A \\
\hline Review Category(ies) & Exempt: \# 2 \\
\hline
\end{tabular}

The IRB determined this study qualifies as exempt and is satisfied the provisions for protecting the rights and welfare of all subjects participating in research are adequate. The study may proceed in accordance with the plans submitted (HRPP Forms enclosed). Please note the following ongoing Human Research Protection Program (HRPP) requirements:

IMPORTANT: In-person interactions for the purposes of conducting human subjects research is suspended until further notice. Data collection must be through remote/virtual methodologies until this restriction is lifted OR an exception to perform in-person data collection is granted by Research \& Graduate Studies.

Changes to Study Activities: Any changes to the study must be submitted to the HRPP for review and determination prior to implementation.

Unanticipated Problems or Adverse Events: Notify the HRPP within 5 days of any unanticipated problems or adverse events that occur as a result of the study.

Study Completion: Notify the HRPP when the study is complete; the HRPP will request annual updates on the study status. Study materials must be kept for at least three years following completion.

Compliance: The PSU IRB (FWA00000091; IRB00000903) and HRPP comply with 45 CFR Part 46, 21 CFR Parts 50 and 56, and other federal and Oregon laws and regulations, as applicable.

If there are any questions, please contact the HRPP at psuirb@pdx.edu or call 503-725-5484.

Sincerely,

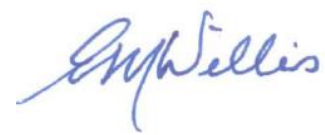

Eva M. Willis, CIP, HRPP Administrator Research Integrity \& Compliance 
April 92021

Andrew MacLean

Department of Applied Linguistics

Portland State University

Re: High-Stakes Education: Dual-Language Immersion Programs in Portland, Oregon

Dear Andrew:

The Portland Public Schools (PPS) System Planning and Performance department has reviewed and approved your request to conduct your research entitled, High-Stakes Education: Dual-Language Immersion Programs in Portland, Oregon. The study is consistent with Board policy and professional research practices. This project is approved as action research for the 2020-21 school year.

This approval provides you with clearance to seek participation from appropriate sites within the school district. Please use this approval letter in your introduction to schools so that district staffs know your research has been approved. Participation in the study by the schools is voluntary. District staff and students are not obligated to participate in outside research, regardless of approval by the System Planning and Performance Department.

Should you need to make changes to your research after this approval is granted, you must submit changes in writing (e-mail is fine) to this department and receive additional approval for requested changes. PPS reserves the right to retract permission to continue your research at any time.

Please note that paid researchers must have worker compensation coverage while on school property. Researchers working directly with students must also complete a PPS volunteer background check. Background checks take about five working days. Researchers meeting with students when a PPS employee is not present must also be fingerprinted by our Security Services Department. For additional information about completing these steps, please visit the PPS Security Services Department web page at: https://www.pps.net/Page/113.

Please keep appropriate administrative staff at study sites updated on the progress of your research. The District is interested in receiving information on the results of this study when they become available. Please submit a copy of the final report to this office. We wish you every success in this study.

Sincerely,

System Planning and Performance Portland Public Schools 